\title{
Ethnologies
}

\section{Our Cannibals, Ourselves. By Priscilla Walton. (Urbana and Chicago: University of Illinois Press, 2004. Pp. ix + 172, Acknowledgments, notes, works cited, index, ISBN 0-25202-925-9)}

\section{Andrea Kitta}

Volume 29, numéro 1-2, 2007

Retour à l'ethnographie

Back to Ethnography

URI : https://id.erudit.org/iderudit/018765ar

DOI : https://doi.org/10.7202/018765ar

Aller au sommaire du numéro

Éditeur(s)

Association Canadienne d'Ethnologie et de Folklore

ISSN

1481-5974 (imprimé)

1708-0401 (numérique)

Découvrir la revue

Citer ce compte rendu

Kitta, A. (2007). Compte rendu de [Our Cannibals, Ourselves. By Priscilla

Walton. (Urbana and Chicago: University of Illinois Press, 2004. Pp. ix + 172,

Acknowledgments, notes, works cited, index, ISBN 0-25202-925-9)]. Ethnologies,

29(1-2), 374-376. https://doi.org/10.7202/018765ar d'utilisation que vous pouvez consulter en ligne.

https://apropos.erudit.org/fr/usagers/politique-dutilisation/ 
make a convincing argument that chimpanzees have the potential to meet the criteria that would admit them to the "Culture Club."

This book would be of interest to those in the social sciences. Whereas the data currently available falls short of indicating that nonhuman primates have culture, it raises several controversial points. By generating discussion and possibly cooperation amongst these disciplines, we might get closer to answering the issues raised.

Sandra Wright

Sir Wilfred Grenfell College

Corner Brook, Newfoundland

\section{Reference}

Kroeber, Alfred Louis. 1928. "Sub-human culture beginnings." Quarterly Review of Biology 3: 325-342.

Our Cannibals, Ourselves. By Priscilla Walton. (Urbana and Chicago: University of Illinois Press, 2004. Pp. ix + 172, Acknowledgments, notes, works cited, index, ISBN 0-25202-925-9)

Our Cannibals, Ourselves is an interdisciplinary look at a clash in cultures. In this book, Walton attempts to show what happens when two conflicting cultures (in this case, European and non-European) meet and the stories that inevitably result. Walton considers the concept of an unknown and possibly dangerous "Other" and the impact when contact with that "Other" is brought home. She also explores "modern day" cannibal stories, which include germs and contamination, Cold War narratives and vampire tales, Mad Cow disease, eating disorders, serial killers, and the consumption of culture.

Although Walton's concepts are intriguing, they are not always well executed. In several places, Walton begins to clearly explain the linkage between cannibals and her more modern subject matter, only later to make leaps in logic which do not include her readers. Her concepts are extremely interesting and engaging; however, the reader may get the impression that they are never fully explained or linked in a manner which is evidentially conclusive. Entire concepts, such as transubstantiation (the changing of bread and wine to body and blood in the Catholic mass), are barely mentioned even though a concept 
such as this is vital when considering European culture and the conflicts between Catholics and non-Catholics within that culture. A discourse such as this would have given strength to Walton's arguments.

Although Walton does use a number of literary texts and films, she completely ignores contemporary legends specifically and folklore scholarship in general, which would have given additional strength to her theses. A consideration of contemporary legends, such as "The Blood Libel" and "The Accidental Cannibal" would have given depth to her treatment of this topic and could have served to reinforce many of her key points. Walton briefly mentions the contemporary legend concerning the stolen kidney in her section on serial killers, but she does not mention any of the scholarship concerning this legend. It is unclear whether Walton is unaware of these sources or if she has chosen to ignore them. Even her brief mention of Hansel and Gretel does not reference the Grimms' work, but instead is a diluted Disney-esque version of the original folktale. Since the publishers laud this book as an "interdisciplinary study of cannibalism in contemporary culture," it is alarming that an entire field of study, which focuses on this very subject, is not addressed.

However, Walton's consideration of various literary texts and films is engaging. Some of her clearest examples come from these portions of the text making these sections the best parts of this work. Walton clearly illustrates many of her points concerning cannibalism and its linkage to "modern cannibalism" through the use of these examples. Her discourse on eating disorders was engaging, although more examples (including the use of Atwood's The Edible Woman) would have enhanced this section further. Also interesting is her section on serial killers and literary and media examples of them. However, in this chapter, Walton makes a sudden shift from serial killers to transplanted organs and organ theft with no real transition. The reader, although still captivated, is left to question how one links to the other. More so, the reader is left feeling unfulfilled as if Walton was only getting started and then forced to end suddenly. Clearly, any work on cannibalism, especially one with this many modern examples, should be longer than 172 pages.

Walton's discourse on consumer cannibalism does give her audience a bit more to digest. In this section, Walton manipulates the idea of consumer in a variety of ways, both as consumers of flesh and of culture. However, again, Walton would have found the work of folklorists and 
others in the social sciences as quite a boon to many of her ideas. The support and examples she could have found in Foodways scholarship alone is both astounding and heartbreaking at times.

In the end, Walton shows that "they" have become "us" through various cannibalistic examples. Although there is no arguing that there is a dichotomy between "us" and "them" especially in the case of cannibalism, the reader may find it hard to swallow that "we" (i.e. Europeans) were ever innocent of cannibalistic charges from the start. Although the use of flesh eating has frequently been used as a way to define "otherness," Walton never sufficiently makes one believe that we were not cannibals from the beginning, albeit a different type of cannibal. An argument that cannibalism has continued and is recognized for what it is would be stronger than an argument that we have become cannibals, therefore become the much feared "Other".

Although film critics and literary scholars may find this work useful, most social scientists including anthropologists and folklorists, will find this work falls short. There are too many logical leaps and too few references to interdisciplinary scholarship to satisfy many academics. Perhaps it is the cannibal in all of us that hungers for the author's logic and numerous examples to satisfy our appetites. Although Walton's ideas waft above us like pleasant aromas, we need more to chew on so that we can digest some of these delicious ideas.

Andrea Kitta

Memorial University of Newfoundland St. John's, Newfoundland

\section{The Heavens Are Changing: Nineteenth-Century Protestant Missions and} Tsimshian Christianity. By Susan Neylan. (Montreal and Kingston: McGillQueen's University Press, 2003. Pp.xvii + 401, ISBN 0-7735-2573-4)

In a broad sense, the purpose of Susan Neylan's study of Protestant Christian missions "in their first generation on the North Pacific Coast of British Columbia (1857-1901)" and her specific focus on "Native roles in Christianization" (5) is to challenge the often superficial dichotomies that inform much scholarship in the field of Aboriginal studies. More specifically, Neylan attempts to detract from a EuroCanadian focus on Aboriginal victimization: focusing on "the discourses 